\title{
Removal of Bromide from Desalinated Water Using Hydrotalcite
}

\author{
Takaaki Wajima
}

\begin{abstract}
Bromide ( $\mathrm{Br}^{-}$) can form disinfection by-products (DBPs) in drinking water sterilization (chlorination or ozonation) processes, and these DBPs have adverse effects on human health. In this study, we tried to remove $\mathrm{Br}^{-}$from desalinated water, which was produced from seawater by spray flash desalination, using hydrotalcite (HT), before sterilization, for use as drinking water. Although $\mathrm{HT}$ did not remove $\mathrm{Br}$ from desalinated water by ion exchange, calcined $\mathrm{HT}$ removed $\mathrm{Br}^{-}$by reconstruction. $\mathrm{Br}^{-}$removal by reconstruction of calcined HT became saturated at sample/solution $=2 \mathrm{~g} / \mathrm{L}$ after reaction for $2 \mathrm{~h}$, and increased with increasing temperature. The adsorption kinetics was examined based on pseudo-first-order and pseudo-second-order reaction models, and the adsorption rate constants for these kinetics models were calculated. Adsorption experiments demonstrated that the adsorption process fitted a pseudo-second-order kinetics model better than a pseudo-first-order model.
\end{abstract}

Index Terms $-\mathrm{Br}^{-}$removal, hydrotalcite, ion exchange, reconstruction.

\section{INTRODUCTION}

The development of sustainable water resources is a major issue for the 21st century [1]. Water resources are essential for agriculture, industry, environmental protection, ecology, and human life. Recently, with population growth, industrialization, and urbanization, problems caused by deteriorating water quality, climate change, and other factors have arisen in all parts of the world. Desalination is one possible solution, and many sectors have a keen interest in desalination technology, which produces fresh water from the almost inexhaustible supplies of seawater.

Multi-stage flash (MSF) and reverse osmosis (RO) membrane methods are widely known. Spray flash desalination uses relatively small temperature differences as the heat source, so this method can use the waste heat from MSF and other plants as an energy source. This technique is also expected to be an effective means of using waste energy, as a countermeasure against global warming and related issues [2], [3].

Desalination using untapped energy is one way of solving this problem, and upward jet spray flash desalination plants are promising in terms of efficiency and compactness. In a previous study, fresh water was produced from surface seawater in Imari Bay using an upward jet spray flash

Manuscript received August 9, 2013; revised September 29, 2013. This work was supported by the Cooperative Research Program of the Institute of Ocean Energy, Saga University (13003A).

Takaaki Wajima is with the Department of Urban Environment Systems, Graduate School of Engineering, Chiba University, Japan (e-mail: wajima@ tu.chiba-u.ac.jp). desalination plant, and the principal components of seawater were removed; however, bromide $\left(\mathrm{Br}^{-}\right)$remained in the water produced [4].

It is well known that disinfection is used to kill pathogens during drinking water treatment. However, an obvious drawback of disinfection is the formation of disinfection by-products (DBPs) [5], [6]. Although $\mathrm{Br}^{-}$is generally considered to be non-toxic at the concentrations found in most drinking water sources, it reacts with a variety of commonly used disinfectants, most notably ozone, chlorine, and chloramine, to produce bromo-DBPs. For example, $\mathrm{Br}$ can be oxidized by ozone to generate bromate, which is highly toxic to humans. According to the World Health Organization standard, $25 \mu \mathrm{g} / \mathrm{L}$ is the maximum concentration of $\mathrm{Br}^{-}$permitted in drinking water [7]. Chlorine or chloramine can rapidly oxidize $\mathrm{Br}^{-}$to hypobromous acid, yielding mixed bromo- or bromochloro-trihalomethanes (THMs) and haloacetic acids (HAAs) by reacting with natural organic matter [8-10]. The US Environmental Protection Agency limits for the maximum concentrations of THMs and HAAs in disinfectant/DBPs [rule (D/DBP) I] are 80 and $60 \mu \mathrm{g} / \mathrm{L}$, respectively [11]. Bromo- or bromochloro-THMs and HAAs are generally considered to be more carcinogenic than their chlorinated analogs [4], [8], [9]. Accordingly, $\mathrm{Br}^{-}$, which is a crucial precursor in the formation of bromo-DBPs, should be removed before disinfection during drinking water treatment

Many studies have been conducted on $\mathrm{Br}^{-}$removal. Electrochemical treatment is sufficient for removing $\mathrm{Br}^{-}$ through oxidation, but it generates by-products in the process [12]. Nanofiltration can also be used to remove this ion with good results, but the high cost limits its large-scale application [13]. Coagulation is also considered to be an effective alternative for removing $\mathrm{Br}^{-}$[14]. However, treatment of the sludge after coagulation must be seriously considered as it contains most of the removed $\mathrm{Br}^{-}$, which is harmful to the environment. Adsorption is one feasible method for $\mathrm{Br}^{-}$removal from solution. For example, $\mathrm{Br}$ removal by Ag-doped activated carbon aerogels, and the effect of these aerogels on $\mathrm{Br}^{-}$behavior, have been investigated [15].

In this study, we focused on hydrotalcite (HT) as a low-cost adsorbent for $\mathrm{Br}^{-}$removal from desalinated water. Layered double hydroxides (LDHs), or HT-like compounds, can be represented by the general formula $\left[\mathrm{M}^{2+}{ }_{1-x} \mathrm{M}^{3+}{ }_{x}(\mathrm{OH})_{2}\right]^{x+}\left(\mathrm{A}^{n-}\right)_{x / n} \cdot \mathrm{mH}_{2} \mathrm{O}$, where $\mathrm{M}^{2+}$ and $\mathrm{M}^{3+}$ are di- and tri-valent metal cations such as $\mathrm{Mg}^{2+}$ and $\mathrm{Al}^{3+}$, which occupy octahedral sites in the hydroxide layers. $\mathrm{A}^{n-}$ is an exchangeable anion, and $x$ is the ratio of $\mathrm{M}^{3+} /\left(\mathrm{M}^{2+}+\mathrm{M}^{3+}\right)$, and the layer charge depends on the $\mathrm{M}^{2+} / \mathrm{M}^{3+}$ ratio [16]. 
Carbonates are the interlayer anions in naturally occurring HT. LDHs have large surface areas $\left(20-120 \mathrm{~m}^{2} / \mathrm{g}\right)$ and high ion-exchange capacities for adsorption/ion-exchange of various anionic pollutants. LDHs decompose at $500-800{ }^{\circ} \mathrm{C}$ to a magnesium-aluminum oxide solid solution, which is rehydrated and reconstructs the original structure from water containing anions [17]; they are therefore potential adsorbents for anionic solutes. Calcined LDHs are particularly interesting adsorbents because they have the potential to remove $\mathrm{F}^{-}, \mathrm{Cl}^{-}$, and other toxic anions from contaminated water [18-24].

In this work, the removal of $\mathrm{Br}^{-}$from desalinated water by calcined and uncalcined $\mathrm{MgAl}-\mathrm{CO}_{3}$ LDHs, by reconstruction and ion exchange, respectively, was studied.

\section{EXPERIMENTAL METHOD}

\section{A. Samples}

The desalinated water used in this study was produced by the flash desalination plant at the Institute of Ocean Energy, Saga University, Japan [4]. The conductivity, salinity, chemical composition, and $\mathrm{pH}$ of the desalinated water and the seawater before the flash desalination treatment are shown in Table I. Although seawater has high conductivity and high salinity, the conductivity $(<0.5 \mathrm{mS} / \mathrm{m})$ and salinity of the desalinated water were quite low, indicating a higher degree of purity than that of fresh water $(1 \mathrm{mS} / \mathrm{m})$ produced by RO desalination of common tap water $(20 \mathrm{mS} / \mathrm{m})$. The seawater contained high concentrations of $\mathrm{Na}^{+}, \mathrm{Cl}^{-}$, and other ions. The principal components and $\mathrm{B}$ fulfilled the criteria for tap water, but the $\mathrm{Br}^{-}$concentration in the sample $(1.9 \mathrm{mg} / \mathrm{L})$ was higher than that in tap water $(10-100 \mu \mathrm{g} / \mathrm{L})$. The $\mathrm{pH}$ of the desalinated water was 5.0. The desalinated water could therefore be used for drinking water after $\mathrm{Br}^{-}$removal.

TABLE I: CONDUCTIVITY, SALINITY, CHEMICAL COMPOSITION, AND PH OF DESALINATED WATER AND SEAWATER

\begin{tabular}{ccc}
\hline \hline & Desalinated water & Seawater \\
\hline Conductivity (mS/m) & 0.497 & 4350 \\
\hline Salinity (\%) & N.D. & 2.71 \\
\hline Content (mg/L) & & \\
$\mathrm{Na}^{+}$ & 1.1 & 10329 \\
$\mathrm{~K}^{+}$ & N.D. & 471 \\
$\mathrm{Mg}^{2+}$ & N.D. & 1305 \\
$\mathrm{Ca}^{2+}$ & N.D. & 376 \\
$\mathrm{Cl}^{-}$ & N.D. & 19410 \\
$\mathrm{Br}^{-}$ & 1.9 & 58 \\
$\mathrm{SO}_{4}{ }^{2-}$ & N.D. & 2140 \\
$\mathrm{~B}$ & 0.2 & 8.2 \\
\hline $\mathrm{pH}$ & 5.0 & 8.1 \\
\hline \hline
\end{tabular}

N.D.: Not determined.

HT was synthesized as follows. $\mathrm{MgCl}_{2}$ solution $(0.6 \mathrm{M}$, $100 \mathrm{~mL})$ and $\mathrm{AlCl}_{3}$ solution $(0.2 \mathrm{M}, 100 \mathrm{~mL})$ were mixed and stirred with a magnetic stirrer at room temperature. During stirring, the $\mathrm{pH}$ of the solution was adjusted to 10.5 by dropwise addition of $0.15 \mathrm{M} \mathrm{Na}_{2} \mathrm{CO}_{3}$ solution. After stirring for $48 \mathrm{~h}$, the slurry was filtered, washed with distilled water, and then dried overnight in a drying oven to obtain the HT sample. The calcined HT (CHT) sample was prepared by heating $\mathrm{HT}$ at $600{ }^{\circ} \mathrm{C}$ for $1 \mathrm{~h}$ in an electric oven.

\section{B. Experimental Procedure}

\section{1) Addition of $H T$ and $C H T$}

Different amounts of HT or CHT (0-0.3 g) were added to $100 \mathrm{~mL}$ of desalinated water. The mixtures were stirred with a magnetic stirrer for $1 \mathrm{~d}$ at room temperature. After stirring, the slurries were filtered and the $\mathrm{pHs}$ of the filtrates and their $\mathrm{Br}^{-}$concentrations were determined.

\section{2) Reaction time for $\mathrm{Br}^{-}$removal}

HT (1 g) or CHT ( $1 \mathrm{~g}$ ) was added to $500 \mathrm{~mL}$ of desalinated water and the mixture was stirred with a magnetic stirrer at room temperature. During stirring, the $\mathrm{pH}$ of the solution was monitored, and $3 \mathrm{~mL}$ aliquots of each slurry were removed at various times, from 0 to $24 \mathrm{~h}$. The aliquots were filtered, and the concentrations of $\mathrm{Br}^{-}$in the filtrates were determined.

\section{3) Effect of temperature on $\mathrm{Br}^{-}$removal}

CHT $(1 \mathrm{~g})$ was added to $500 \mathrm{~mL}$ of desalinated water and the mixture was stirred with a magnetic stirrer at 5-80 ${ }^{\circ} \mathrm{C}$. During stirring, the $\mathrm{pH}$ of the solution was monitored, and 3 $\mathrm{mL}$ aliquots of each slurry were removed at various times, from 0 to $3 \mathrm{~h}$. The aliquots were filtered, and the concentrations of $\mathrm{Br}^{-}$in the filtrates were determined.

\section{4) Chemical analysis}

The electrical conductivities and salinities of the seawater and desalinated water were measured using a conductivity meter (ES-51, Horiba, Japan). The concentration of B, which is vital in desalination, was measured using inductively coupled plasma atomic emission spectroscopy (ICPS-7500, Shimadzu, Japan). The solution $\mathrm{pH}$ was measured with a $\mathrm{pH}$ meter (D-53, Horiba, Japan), and the $\mathrm{Br}^{-}$concentration in the solution was determined using ion chromatography (ICS-3000, Dionex, Japan). The $\mathrm{Br}^{-}$uptake by CHT, $q$ $(\mathrm{mg} / \mathrm{g})$, and the percentage $\mathrm{Br}^{-}$removal, $R(\%)$, were evaluated using the following equations:

$$
\begin{gathered}
q=\frac{\left(C_{0}-C\right) V}{m} \\
R=\frac{\left(C_{0}-C\right)}{C_{0}} \times 100
\end{gathered}
$$

where $C_{0}$ and $C$ are the initial and residual $\mathrm{Br}^{-}$concentrations in the solution $(\mathrm{mg} / \mathrm{L})$, respectively, $V$ is the solution volume (L), and $m$ is the mass of adsorbent (g).

\section{RESUlTS AND DISCUSSION}

Fig. 1 shows (a) the solution $\mathrm{pHs}$ and (b) the $\mathrm{Br}^{-}$ concentrations in the solutions after treatment with HT and CHT. The solution $\mathrm{pH}$ after treatment with $\mathrm{CHT}$ was higher than that after treatment with $\mathrm{HT}$, increasing to $\mathrm{pH} 11$ and $\mathrm{pH}$ 8.5 with increasing addition of $\mathrm{CHT}$ and $\mathrm{HT}$, respectively, as a result of the production of $\mathrm{OH}^{-}$ions [25], [26]. Little decrease in the $\mathrm{Br}^{-}$concentration occurred on treatment with $\mathrm{HT}$, but the $\mathrm{Br}^{-}$concentration decreased significantly when treated with $\mathrm{CHT}$ at more than $2 \mathrm{~g} / \mathrm{L}$; this was in good agreement with the $\mathrm{pH}$ behavior of the solution. It is considered that the reconstruction reaction for the uptake of 
$\mathrm{Br}^{-}$from the solution occurred strongly on addition of more than $2 \mathrm{~g} / \mathrm{L}$ of CHT.
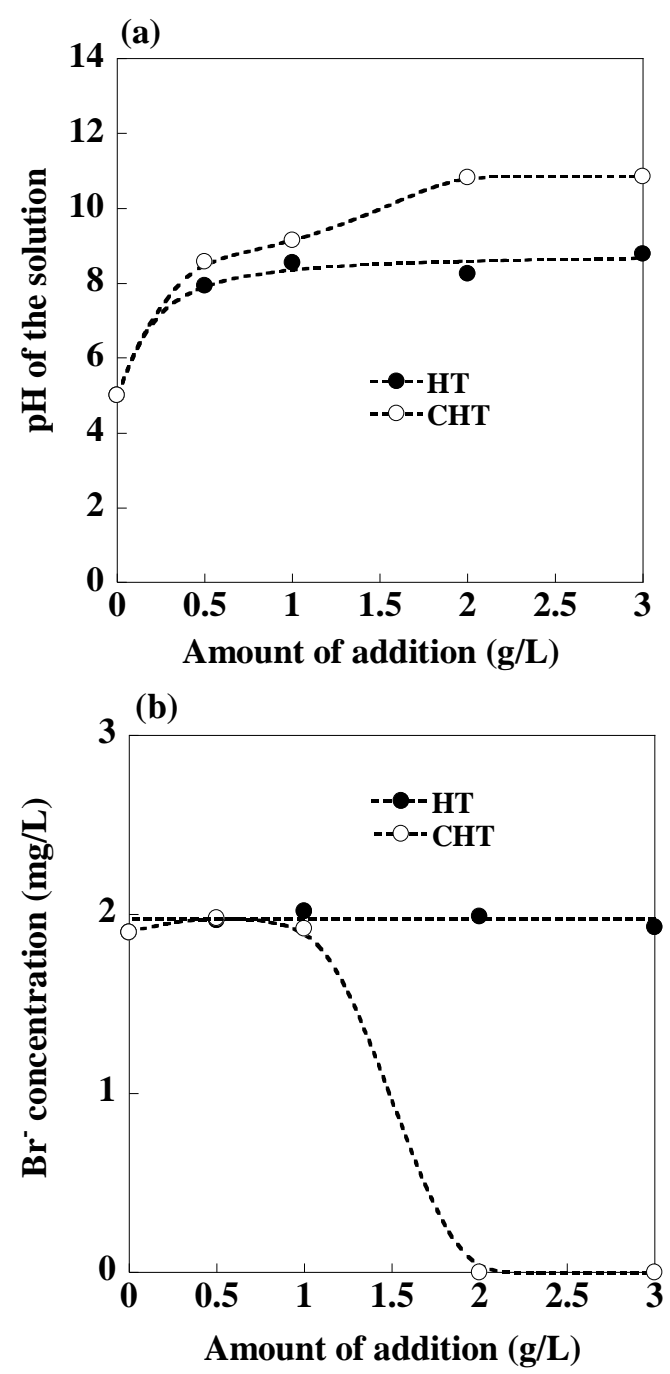

Fig. 1. Effects of HT and CHT addition on (a) solution $\mathrm{pH}$ and (b) $\mathrm{Br}^{-}$ concentration.

Fig. 2 shows the (a) pHs and (b) $\mathrm{Br}^{-}$concentrations of solutions during treatment with HT and CHT. The solution $\mathrm{pH}$ rapidly increased to 8.5 and 11 in the initial stage, and then became almost constant, on treatment with HT and $\mathrm{CHT}$, respectively. Although the concentrations of $\mathrm{Br}^{-}$were unchanged by treatment with HT because the anion selectivity order of the ion-exchange reaction with $\mathrm{HT}$ is $\mathrm{Br}^{-}$ $<<\mathrm{CO}_{3}{ }^{2-}$ [27-29], they gradually decreased over $2 \mathrm{~h}$ to zero on treatment with $\mathrm{CHT}$. $\mathrm{Br}^{-}$can therefore be removed from desalinated water using CHT.

Fig. 3 shows the $\mathrm{Br}^{-}$concentrations of the solutions and the removal of $\mathrm{Br}^{-}$from desalinated water during treatment with $\mathrm{CHT}$ at $5,15,25,50$, and $80{ }^{\circ} \mathrm{C}$. With increasing temperature, the decrease in $\mathrm{Br}^{-}$concentration in the solution to zero became faster, and the removal of $\mathrm{Br}^{-}$from desalinated water was promoted. Above $50{ }^{\circ} \mathrm{C}, \mathrm{Br}^{-}$removal reached $100 \%$ within $0.5 \mathrm{~h}$. These results suggest that desalination treatment with $\mathrm{CHT}$ at high temperatures gives better $\mathrm{Br}^{-}$removal than treatment at low temperatures does.

The kinetics of the adsorption of $\mathrm{Br}^{-}$from desalinated water at 5,15 , and $25{ }^{\circ} \mathrm{C}$, and the adsorption capacities of $\mathrm{CHT}$ for $\mathrm{Br}^{-}$at 5,15 , and $25^{\circ} \mathrm{C}$ were studied; the results are shown in Fig. 4(a). The equilibrium state was reached more quickly with increasing temperature.

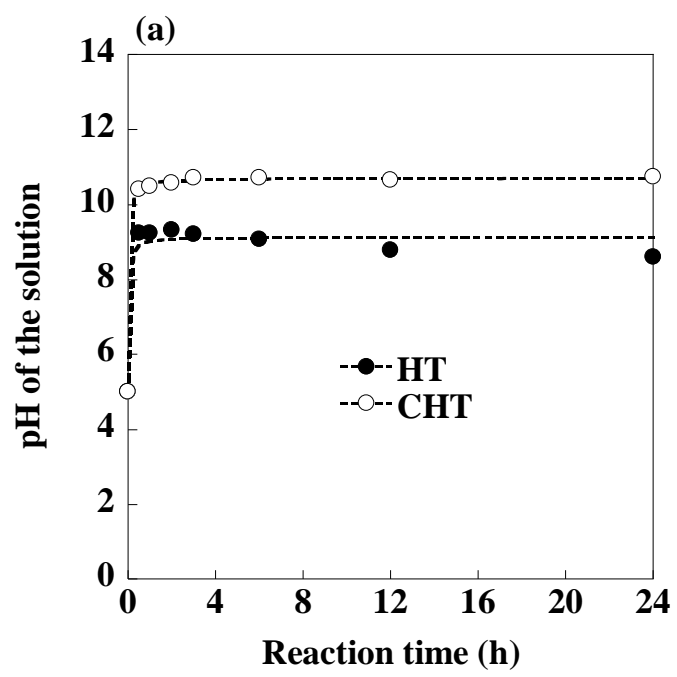

(b)

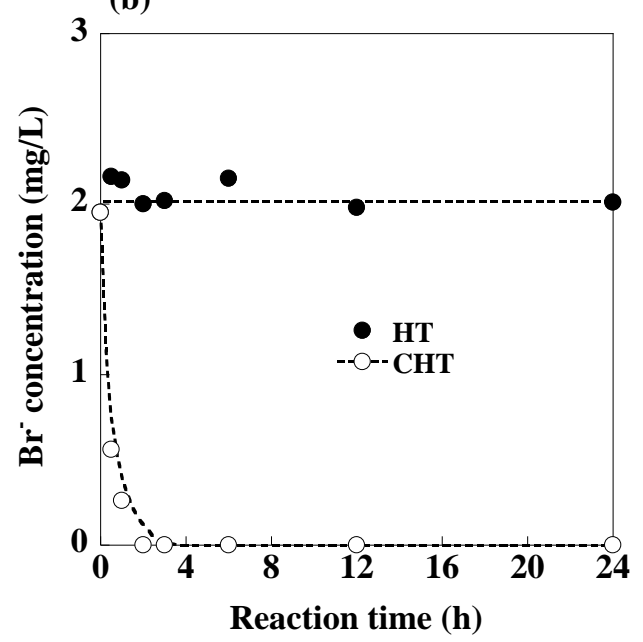

Fig. 2. Effects of reaction time on (a) solution $\mathrm{pH}$ and (b) $\mathrm{Br}^{-}$concentration in solutions treated with HT and CHT.

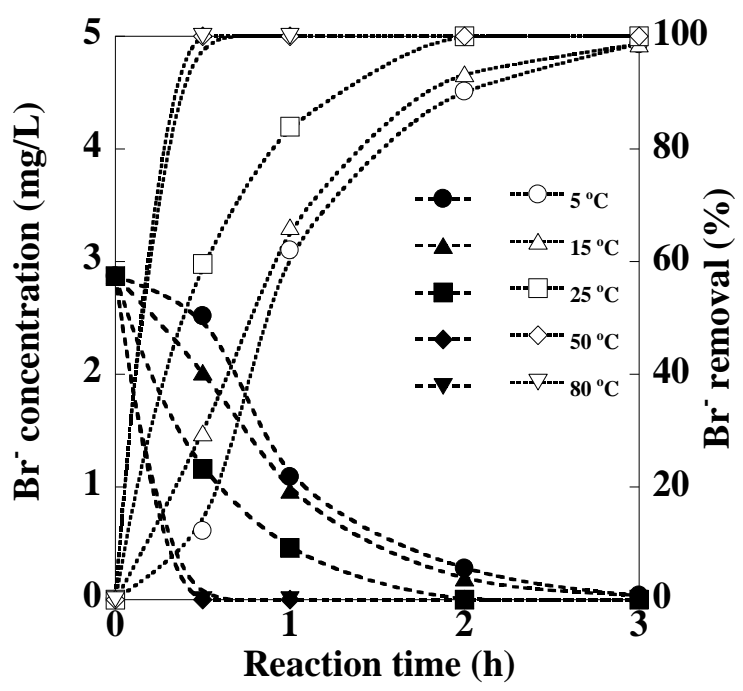

Fig. 3. $\mathrm{Br}^{-}$concentrations in solutions and removal of $\mathrm{Br}^{-}$from desalinated water during treatment with $\mathrm{CHT}$ at $5,15,25,50$, and $80^{\circ} \mathrm{C}$.

The kinetics of the adsorption process were investigated using pseudo-first-order and pseudo-second-order equations, i.e., equations (3) and (4), respectively, to analyze the experimental data. 


$$
\begin{gathered}
\ln \left(q_{e}-q_{t}\right)=\ln q_{e}-k_{1} t \\
\frac{t}{q_{t}}=\frac{1}{k_{2} q_{e}{ }^{2}}+\frac{1}{q_{e}}
\end{gathered}
$$

where $q_{\mathrm{e}}$ and $q_{t}$ are the amounts of $\mathrm{Br}^{-}$adsorbed at equilibrium and at time $t(\mathrm{~h})$, and $k_{1}\left(\mathrm{~h}^{-}\right)$and $k_{2}\left(\mathrm{~g} \cdot \mathrm{mg}^{-1} \cdot \mathrm{h}^{-1}\right)$ are the adsorption rate constants of the pseudo-first-order and pseudo-second-order equations, respectively. Fig. 4(b) and Fig. (c) show the linearized forms of the pseudo-first-order and pseudo-second-order models for $\mathrm{Br}^{-}$adsorption onto CHT. The kinetics parameters were calculated from the slopes and intercepts of the linear plots of $\ln \left(q_{\mathrm{e}}-q_{t}\right)$ versus $t$, and $t / q_{t}$ versus $t$; the results are summarized in Table II.
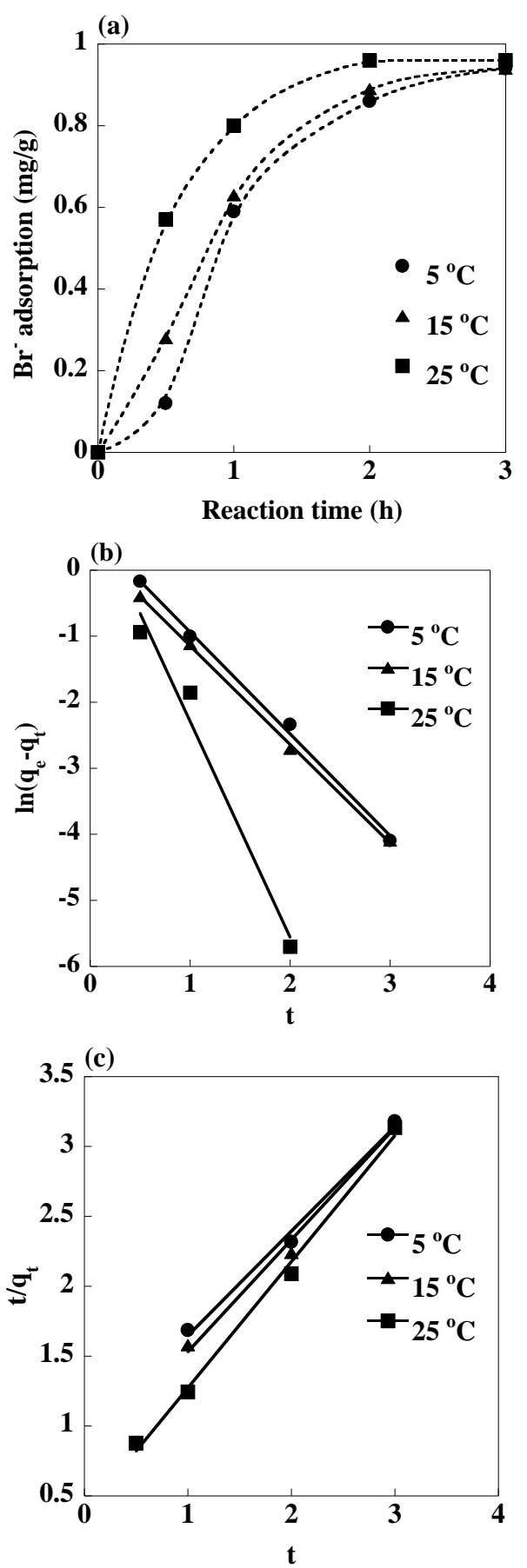

Fig. 4. (a) Adsorption of $\mathrm{Br}^{-}$from desalinated water onto $\mathrm{CHT}$ at 5, 15, and $25^{\circ} \mathrm{C}$, (b) pseudo-first-order kinetics study of $\mathrm{Br}^{-}$adsorption onto CHT at 5, 15 , and $25^{\circ} \mathrm{C}$, and (c) pseudo-second-order kinetics study of $\mathrm{Br}^{-}$adsorption onto CHT at 5,15 , and $25^{\circ} \mathrm{C}$.
TABLE II: KINETICS PARAMETERS FOR BR ${ }^{-}$ADSORPTION ONTO CHT

\begin{tabular}{ccccccc}
\hline \hline & \multicolumn{3}{c}{$\begin{array}{c}\text { Pseudo-first-order } \\
\text { equation }\end{array}$} \\
$\begin{array}{c}\text { Temperature } \\
\left({ }^{\circ} \mathrm{C}\right)\end{array}$ & $\begin{array}{c}k_{1} \\
\left(\mathrm{~h}^{-1}\right)\end{array}$ & $\begin{array}{c}q_{\mathrm{e}} \\
(\mathrm{mg} / \mathrm{g})\end{array}$ & $R^{2}$ & $\begin{array}{c}k_{2} \\
\left(\mathrm{~g} \cdot \mathrm{mg}^{-1} \cdot \mathrm{h}^{-1}\right)\end{array}$ & $\begin{array}{c}q_{\mathrm{e}} \\
(\mathrm{mg} / \mathrm{g})\end{array}$ & $R^{2}$ \\
\cline { 2 - 7 } & 1.542 & 1.831 & 0.997 & 0.621 & 1.34 & 0.992 \\
15 & 1.493 & 1.417 & 0.999 & 0.876 & 1.25 & 0.990 \\
25 & 3.271 & 2.674 & 0.977 & 2.210 & 1.11 & 0.995 \\
\hline \hline
\end{tabular}

The $R^{2}$ coefficients for the pseudo-first-order and pseudo-second-order models are high $(>0.99)$ and have almost the same values, except in the case of the pseudo-first-order model at $25{ }^{\circ} \mathrm{C}$. The theoretical $q_{e}$ for the pseudo-second-order model is $1.11-1.34 \mathrm{mg} / \mathrm{g}$, which is closer to the experimental $q_{e}$ than the $q_{e}$ for the pseudo-first-order model is. These results indicated that the pseudo-second-order model adequately describes the kinetics of $\mathrm{Br}^{-}$adsorption from desalinated water onto $\mathrm{CHT}$.

The activation energy for $\mathrm{Br}^{-}$adsorption from desalinated water onto $\mathrm{CHT}$ was calculated using the Arrhenius equation:

$$
k_{2}=A \bullet \exp \left(-\frac{\Delta E}{R T}\right)
$$

where $\Delta E$ is the activation energy $(\mathrm{kJ} / \mathrm{mol}), A$ is the frequency factor, $T$ is the absolute temperature $(\mathrm{K})$, and $R$ is the gas constant. The activation energy for the adsorption of $\mathrm{Br}^{-}$from desalinated water onto $\mathrm{CHT}$ was calculated to be $43.5 \mathrm{~kJ} / \mathrm{mol}$ from the plot of $\ln k_{2}$ versus $1 / T$ (Fig. 5).

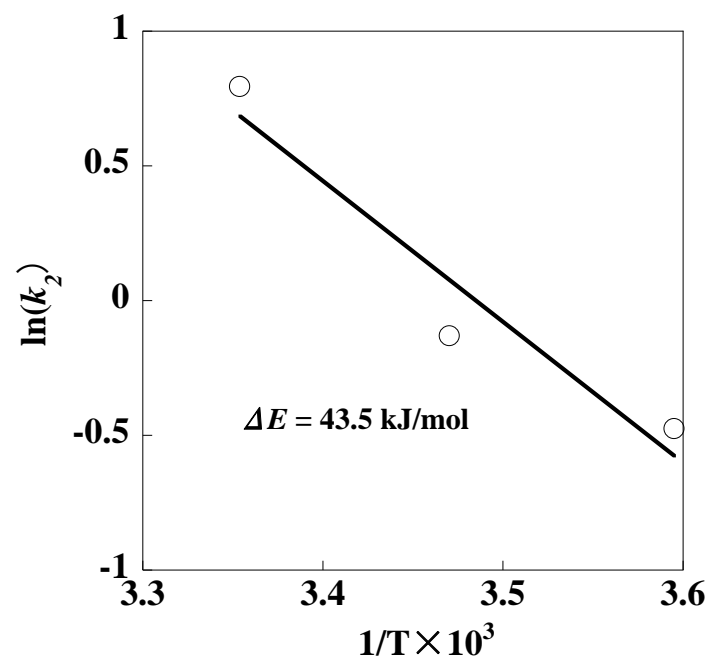

Fig. 5. Arrhenius plot for $\mathrm{Br}^{-}$adsorption from desalinated water onto CHT.

\section{CONCLUSION}

To establish an effective use of ocean resources, we used an inorganic anion exchanger, i.e., HT, for $\mathrm{Br}^{-}$removal from desalinated water produced from seawater using upward spray flash desalination. CHT removed large amounts of $\mathrm{Br}^{-}$ from desalinated water, whereas non-calcined HT removed little $\mathrm{Br}^{-}$. The removal of $\mathrm{Br}^{-}$from desalinated water using $\mathrm{CHT}$ increased with increasing temperature. The adsorption kinetics of $\mathrm{Br}^{-}$from desalinated water onto $\mathrm{CHT}$ followed a pseudo-second-order model rather than a pseudo-first-order model. These results indicate that $\mathrm{CHT}$ can reduce the $\mathrm{Br}^{-}$ concentration in desalinated water, and has possible 
applications as an adsorbent for removal of ions from drinking water before sterilization.

\section{ACKNOWLEDGMENT}

This work was supported by the Cooperative Research Program of the Institute of Ocean Energy, Saga University (13003A).

\section{REFERENCES}

[1] World Water Council, World Water Vision. Making Water Everybody's Business, Earthscan Publications Limited, London, UK, 2002.

[2] Y. Ikegami, H. Sasaki, T. Gouda, and H. Uehara, "Experimental study on a spray flash desalination influence of the direction of injection," Desalin,. vol. 194, pp. 81-89, 2006.

[3] S. Jitsuhara and T. Watanabe, "Ocean thermal energy desalination," $J$. Water Re-Use Technol., vol. 29, pp. 40-43, 2003.

[4] Y. Ikegami, T. Wajima, and H. Sasaki, "Experimental study on desalination of seawater in Imari bay using an upward spray flash desalination plant," Bull. Soc. Sea Water Sci. Jpn., vol. 60, pp. 137-138, 2006.

[5] J. Sohn, G. Amy, J. W. Cho, Y. H. Lee, and Y. M. Yoon, "Disinfectant decay and disinfection by-products formation model development: chlorination and ozonation by-products," Water Res., vol. 38, pp. 2461-2478, 2004.

[6] F. Ge, L. Zhu, and H. Chen, "Effects of $\mathrm{pH}$ on the chlorination process of phenols in drinking water," J. Hazard. Mater., vol. B133, pp. 99-105, 2006.

[7] D. E. Kimbrough and I. H. Suffet, "Electrochemical process for the removal of bromide from California state project water," J. Water Supply: Res. Technol.-AQUA, vol. 55, pp. 161-167, 2006.

[8] R. D. Morris, A. M. Audet, I. F. Angelillo, and T. C. Chalmers, "Chlorination, chlorination by-products, and cancer: a meta-analysis," Am. J. Public Health, vol. 82, pp. 955-963, 1992.

[9] D. A. Reckhow, P. C. Singer, and R. L. Malcolm, "Chlorination of humic materials: by-product formation and chemical interpretations," Environ. Sci. Technol., vol. 24, pp. 1655-1664, 1990.

[10] Y. Xie, I. Rashid, and H. Zhou, "Acidic methanol methylation for HAA analysis: imitations and possible solutions," J. Am. Water Works Assoc., vol. 94, pp. 115-123, 2002.

[11] National Interim Primary Drinking Water Regulations, Fed. Reg. vol. 59, pp. 38668-38829, 1994.

[12] D. E. Kimbrough and I. H. Suffet, "Electrochemical removal of bromide and reduction of THM formation potential in drinking water," Water Res., vol. 36, pp. 4902-4906, 2002.

[13] S. Chellam, "Effects of nanofiltration on trihalomethane and haloacetic acid precursor removal and speciation in waters containing low concentrations of bromide ion," Environ. Sci. Technol., vol. 34, pp. 1813-1820, 2000.

[14] F. Ge and L. Zhu, "Effects of coexisting anions on removal of bromide in drinking water by coagulation," J. Hazard. Mater., vol. 151, pp. 676-681, 2008.

[15] M. S. Polo, J. R. Utrilla, E. Salhi, and V. U. Gunten, "Removal of bromide and iodide anions from drinking water by silver-activated carbon aerogels," J. Colloid Interface Sci., vol. 300, pp. 437-441, 2006

[16] X. Liang, Y. Zang, Y. Xu, X. Tan, W. Hou, L. Wang, and Y. Sun, "Sorption of metal cations on layered double hydroxides," Colloids Surf., vol. 433, pp. 122-131, 2013.

[17] S. Miyata, "Physico-chemical properties of synthetic hydrotalcites in relation to composition," Clays Clay Miner., vol. 28, pp. 50-56, 1980.
[18] Y. W. You, H. T. Zhao, and G. F. Vance, "Adsorption of dicamba (3, 6-dichloro-2-methoxybenzonic acid) in aqueous solution by calcined-layered double hydroxide," Appl. Clay Sci., vol. 21, pp. 217-226, 2002.

[19] D. P. Das, J. Das, and K. Parida, "Physicochemical characterization and adsorption behavior of calcined $\mathrm{Zn} / \mathrm{Al}$ hydrotalcite compound (HTlc) towards removal of fluoride from aqueous solution," J. Colloid Interface Sci., vol. 261, pp. 213-220, 2003.

[20] C. D. Nava, M. S. Rios, and M. T. Olguin, "Sorption of fluoride ions from aqueous solutions and well drinking water by thermally treated hydrotalcite," Sep. Sci. Technol., vol. 38, pp. 131-147, 2003.

[21] N. K. Lazaridis and D. D. Asouhidou, "Kinitics of sorptive removal of chromium(VI) from aqueous solutions by calcined $\mathrm{Mg}-\mathrm{Al}-\mathrm{CO}_{3}$ hydrotalcite," Water Res., vol. 37, pp. 2875-2882, 2003.

[22] L. Lv, J. He, M. Wei, D. G. Evans, and X. Duan, "Uptake of chloride ion from aqueous solution by calcined layered double hydroxides: equilibrium and kinetic studies," Water Res., vol. 40, pp. 735-743, 2006.

[23] L. Lv, J. He, M. Wei, D. G. Evans, and X. Duan, "Factors influencing the removal of fluoride from aqueous solution by calcined $\mathrm{Mg}-\mathrm{Al}-\mathrm{CO}_{3}$ layered double hydroxides," J. Hazard. Mater., vol. B133, pp. 119-128, 2006.

[24] L. Lv, J. He, M. Wei, D. G. Evans, and Z. L. Zhou, "Treatment of high fluoride concentration water by $\mathrm{Mg}-\mathrm{Al}-\mathrm{CO}_{3}$ layered double hydroxides: Kinetic and equilibrium studies," Water Res., vol. 41, pp. 1534-1542, 2007.

[25] T. Kameda, T. Yoshioka, and A. Okuwaki, "Development of new synthetic process for hydrotalcite using seawater and calcined dolomite and its application to waste water treatment," Chem. Ind., vol. 52, pp. 810-814, 2001

[26] J. Shibata, N. Murayama, and S. Nakajima, "pH buffer action of layered double hydroxide," Kagaku Kougaku Ronbunshu, vol. 33, pp. 273-277, 2007.

[27] S. Miyata, "Anion-exchange properties of hydrotalcite-like compounds," Clays Clay Miner., vol. 31, pp. 305-311, 1983.

[28] L. M. Parker, N. B. Milestone, and R. H. Newman, "The use of hydrotalcite as an anion adsorbent," Ind. Eng. Chem. Res., vol. 34, pp. 1196-1202, 1995.

[29] S. Tezuka, R. Chitrakar, A. Sonoda, K. Ooi, and T. Tomida, "Studies on selective adsorbents for oxo-anions. Nitrate ion-exchange properties of layered double hydroxides with different metal atoms," Green Chem., vol. 6, pp. 104-109, 2004.

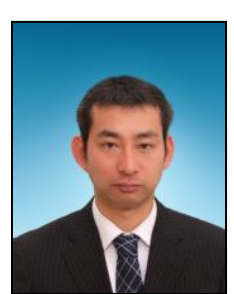

Takaaki Wajima was born in February, 1976 in Saga prefecture, Japan. He has been an associate professor in the Department of Urban Environment Systems, Graduate School of Engineering, Chiba University, Japan, since 2013. He received his bachelor's degree and master's degree in resource engineering from Kyoto University, Japan in 1998 and 2000, respectively, and doctor of philosophy (Ph.D.) degree in environmental mineralogy and technology from Kyoto University, Japan in 2004. His main research theme was "Micro-porous Materials Synthesized from Paper Sludge Ash at Low Temperature, and its Chemical Mineralogy." In 2004, he moved to the Institute of Ocean Energy in Saga University as a postdoctoral researcher, and from 2007 to 2013 he was an assistant professor at Akita University, Japan. His main research interests are waste recycling, resource recovery, and environmental purification. 